malaria (ague) in England. This was followed by an important study of the biology and anatomy of $A$. maculipennis, carried out in collaboration with the late Sir Arthur Shipley. His study of canine piroplasmosis represents the first attempt of investigation in Europe of a disease imported by means of an infected vector-a tick-from South Africa. An important result of this investigation, which has great economic importance, was the discovery of the curative property of trypan blue for piroplasmosis in dogs, cattle and sheep. This study was followed by an extensive investigation of the anatomy, biology, life-history and systematics of ticks carried out in collaboration with Mr. C. Warburton, Dr. L. E. Robinson and others. Most of his time during and after the Great War was given to the study of lice (Pediculus), their life-history, biology and anatomy, and the problems connected with the methods of combating the spread of these parasites.

In 1901 Nuttall founded the Journal of Hygiene and in 1908 Parasitology, both of which he edited with great distinction, setting up a very high standard of publication in this field of biology. During his

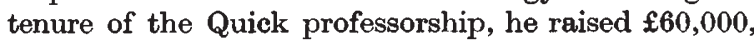
which was expended on building, endowment, and research, and received grants for research workers totalling nearly $£ 12,000$. On his retirement in 1932 , he was presented by his colleagues and pupils with his portrait in oils painted by his friend, the late Philip de Laszló.

Nuttall had a charming manner and was a great conversationalist and excellent raconteur. One has a vivid recollection of him on a hot day last summer, distinguished, indefatigable and ever courteous, leading a number of French scientific investigators round the colleges and retailing in fluent French, anecdotes and stories from his apparently inexhaustible store of knowledge. He was always at ease in whatever company he found himself and had the knack of putting his companions at ease also. $\mathrm{He}$ was never at a loss for the right word or a courteous reply. At international gatherings he was always surrounded by numerous colleagues and was greatly helped in such company by his extensive travels and by his ability readily to speak so many languages. In spite of his multifarious activities, Nuttall found time to collect the photographs of many of the most famous parasitologists and biologists of the past, and this unique collection now adorns the walls of the corridors in the Molteno Institute. During his travels in the course of this long and active scientific career, Nuttall had exceptional opportunities of establishing contact, usually developing into friendship, with many distinguished workers of intermational reputation. He knew intimately several of them and had friendly scientific correspondence with others.

Nuttall's death deprives us of one of the last links with what may be described as the heroic periods in the history of bacteriology and tropical medicine. Nuttall died suddenly, as he always hoped to die, with his enthusiasm and energy little impaired and free from disabilities and sufferings often associated with old age. His wife died in 1922. He is survived by two sons and one daughter.

\section{Capt. H. W. Seton-Karr}

WE regret to record the death of Capt. H. W. Seton-Karr, archæologist, explorer and big-game hunter, who died on January 12 at the age of seventyeight years.

Heywood Walter Seton-Karr, a member of an old Scottish family, was the son of George Berkeley Seton-Karr, resident commissioner of Baroda during the Indian Mutiny. Born in 1859, he was educated at Eton and went up to Oriel College, Oxford, afterwards entering the army. During the Egyptian campaign of the early 'eighties he served in the 92nd Regiment (afterwards the Gordon Highlanders), for which he received the medal, clasp and Khedive's star. He then travelled extensively in Egypt and Somaliland, making a large collection of palæolithic stone implements; these were among the first of extra-European origin to be recognized, and were afterwards described in the Journal of the Anthro. pological Institute. Later he made collections of similar stone implements in India. An assiduous collector, he is said to have presented collections of stone implements gathered on his travels to more than two hundred museums in various countries. In pursuit of big game he made no fewer than thirtynine expeditions to Africa, India and Arctic Europe. $\mathrm{He}$ was an expert painter in water-colours and was commissioned to paint for the Imperial War Museum. His published works included "Shores and Alps of Alaska", "Ten Years' Wild Sport in Foreign Lands" and "Bear Hunting in the White Mountains".

WE regret to announce that the promising young Danish physicist Fritz Kalckar died suddenly from heart-failure a few weeks ago. Although only twentyseven years of age, he was already one of the most brilliant collaborators of the Institute of Theoretical Physics, Copenhagen, and had written a number of interesting papers on various atomic problems. Only a few months before his death he published with Prof. Bohr, in the communications of the Copenhagen Academy, a paper on the recent development of the theory of nuclear reactions, which was intended as the first part of a series of papers on this subject.

We regret to announce the following deaths :

Mr. H. I. Heath, formerly principal of the Mayo School of Arts and Crafts, and curator of the Lahore Museum, on February 10, aged sixty-six years.

Sir Truby King, director of child welfare, Dominion of New Zealand, 1921-27, and author of well-known standard works on the feeding and care of young children and on mothercraft, on F'ebruary 9, aged seventy-nine years.

Dr. Charles Lallemand, formerly Inspecteur général des Mines, France, and president of the International Union of Geodesy and Geophysics in 1919-33, on February 1, aged eighty years.

Dr. John K. Small, director of research and curator of the New York Botanical Garden, known for his work on the flora of the United States, on January 20, aged sixty-eight years. 